CLINICAL STUDY

\title{
The effects of sex-steroid administration on the pituitary-thyroid axis in transsexuals
}

\author{
Peter H Bisschop ${ }^{1}$, Arno W Toorians ${ }^{3}$, Erik Endert ${ }^{2}$, Wilmar M Wiersinga ${ }^{1}$, Louis J Gooren ${ }^{3}$ and Eric Fliers ${ }^{1}$ \\ Department of ${ }^{1}$ Endocrinology and Metabolism and ${ }^{2}$ Clinical Chemistry, Laboratory of Endocrinology, Academic Medical Center, University of Amsterdam, \\ 1105 AZ, Amsterdam, The Netherlands and ${ }^{3}$ The Institute of Endocrinology, Reproduction and Metabolism, University Hospital Vrije Universiteit, \\ 1007 MB Amsterdam, The Netherlands \\ (Correspondence should be addressed to P H Bisschop; Email: p.h.bisschop@amc.uva.nl)
}

\begin{abstract}
Objective: Estrogen and androgen administration modulate the pituitary-thyroid axis through alterations in thyroid hormone-binding globulin (TBG) metabolism, but the effects of sex steroids on extrathyroidal thyroxine $\left(\mathrm{T}_{4}\right)$ to triiodothyronine $\left(\mathrm{T}_{3}\right)$ conversion in humans are unknown.

Design and methods: We studied 36 male-to-female and 14 female-to-male euthyroid transsexuals at baseline and after 4 months of hormonal treatment. Male-to-female transsexuals were treated with cyproterone acetate $(\mathrm{CA}) 100 \mathrm{mg} /$ day alone $(n=10)$ or in combination with either oral ethinyl estradiol (or-EE) $100 \mu \mathrm{g} /$ day $(n=14)$ or transdermal $17 \beta$-estradiol (td-E) $100 \mu \mathrm{g}$ twice a week $(n=12)$. Femaleto-male transsexuals were treated with i.m. testosterone $250 \mathrm{mg}$ twice a week. A $t$-test was used to test for differences within groups and ANOVA with post hoc analysis to test for differences between the groups. Results: Or-EE increased TBG $(100 \pm 12 \%, P<0.001)$ and testosterone decreased TBG $(-14 \pm 4 \%$, $P=0.01)$, but free $\mathrm{T}_{4}$ did not change. Td-E and CA did not affect TBG concentrations. TSH was not different between groups at baseline or after treatment. $C A$ decreased $\mathrm{T}_{3} / \mathrm{T}_{4}$ ratios $(-9 \pm 3 \%, P=0.04)$, suggesting that $\mathrm{T}_{4}$ to $\mathrm{T}_{3}$ conversion was lower. Testosterone increased $\mathrm{T}_{3} / \mathrm{T}_{4}$ ratios $(30 \pm 9 \%, P=0.02)$, which probably reflects higher $\mathrm{T}_{4}$ to $\mathrm{T}_{3}$ conversion.

Conclusion: Oral but not transdermal estradiol increases TBG, whereas testosterone lowers TBG. Testosterone increases $\mathrm{T}_{3} / \mathrm{T}_{4}$ ratios. Estradiol does not affect $\mathrm{T}_{3} / \mathrm{T}_{4}$ ratios, irrespective of the route of administration.
\end{abstract}

European Journal of Endocrinology 155 11-16

\section{Introduction}

Administration of sex hormones can interfere substantially with the hypothalamic-pituitary-thyroid (HPT) axis. Oral estrogen administration increases thyroidhormone-binding globulin (TBG) concentrations (1). This glycoprotein is produced in the liver and binds about two-thirds of serum thyroxine $\left(\mathrm{T}_{4}\right)$. The rise in TBG is paralleled by a $\mathrm{T}_{4}$ increase to maintain a physiological concentration of free $\mathrm{T}_{4}$. Therefore, the $\mathrm{T}_{4}$ substitution dose in women with primary hypothyroidism, characterized by impaired endogenous $\mathrm{T}_{4}$ production, must be increased when oral estrogens are administered (1). In contrast to oral administration, transdermal estrogen administration does not raise TBG concentrations (2). It is assumed that this discrepancy is caused by a first-pass effect due to high portal vein estrogen concentrations after oral administration. Opposite to estrogen, androgen administration in women decreases TBG concentrations and requires reduction of $\mathrm{T}_{4}$ substitution in patients with primary hypothyroidism to avoid thyrotoxicosis (3).
Besides the effects on TBG concentrations, sex hormones also affect deiodinase activity. Peripheral conversion of inactive $\mathrm{T}_{4}$ to biologically active triiodothyronine $\left(\mathrm{T}_{3}\right)$ is catalyzed by $5^{\prime}$-deiodinase activity and is the main source of circulating $\mathrm{T}_{3}$. Two of the three deiodinase subtypes, type 1 (D1) and 2 (D2), have $5^{\prime}$-deiodinase capability. D1 is expressed in the liver of rodents and humans. D2 is expressed in brown adipose tissue of rodents and in muscle of humans. It was recently shown that muscle D2 activity is the major source of circulating $\mathrm{T}_{3}$ in euthyroid humans (4).

In rats, hepatic activity of $5^{\prime}$-deiodinase was not altered by ovariectomy (5), but increased after a supraphysiological dose of $17 \beta$-estradiol (6). The latter effect was blunted by concurrent administration of progestins (6). In orchidectomized rats, hepatic D1 activity was reduced, but could be restored to normal by the substitution of testosterone $(5,6)$. These observations suggest that physiological concentrations of testosterone stimulate D1 activity in male rats and might provide an explanation for higher D1 activity in the liver of normal male rats than in female rats (7). 
The effects of androgens and estrogens on 5'deiodinase activity in humans are not known. For evident reasons, 5'-deiodinase activity cannot be measured as easily in humans as in rodents, but serum $\mathrm{T}_{3} / \mathrm{T}_{4}$ ratios can be used as a marker for $5^{\prime}$-deiodinase activity, since the majority of circulating serum $\mathrm{T}_{3}$ is produced by peripheral conversion of $\mathrm{T}_{4}$ to $\mathrm{T}_{3}$.

To explore the effects of androgens and estrogens on $5^{\prime}$-deiodinase activity, we studied transsexuals receiving standard cross-gender sex-hormone administration and measured the effects on the HPT axis, including $\mathrm{T}_{3} / \mathrm{T}_{4}$ ratios and TBG. The standard hormone administration regimens in male-to-female transsexuals include, among others, a regimen with single agent administration of cyproterone acetate $(\mathrm{CA}) . \mathrm{CA}$ is a progestin with anti-androgenic action by competitive binding to the testosterone receptor. The effects of CA administration on the HPT axis in humans have not been described before and will also be presented.

\section{Materials and method}

\section{Materials}

To study the effect of hormone treatment on the HPT axis, we used plasma samples from an earlier study, which were collected before and after 4 months of hormone administration. The original study was published elsewhere (8) and described the effects of oral and transdermal estrogen administration on tissue-type plasminogen activator levels in 40 male-to-female and 17 female-to-male transsexuals. In this study, 36 maleto-female transsexuals were treated with CA (Androcur, $100 \mathrm{mg} /$ day, Schering, Berlin, Germany) and subsequently open-label randomized to receive oral ethinyl estradiol (EE) (Lynoral, $100 \mu \mathrm{g} /$ day, Organon, Oss, the Netherlands; $n=14$ ), transdermal $17 \beta$-estradiol (Estraderm TTS 100, $100 \mu \mathrm{g}$ twice a week, CIBA-Geigy, Basel, Switzerland; $n=12)$ or no additional treatment $(n=10)$. Female-to-male transsexuals were treated with testosterone esters (Sustanon, $250 \mathrm{mg} / 2$ week i.m., Organon, Oss, the Netherlands). The number of patients in the present study differs slightly from the original study, because the amount of available plasma in seven patients was insufficient to perform the complete evaluation of the pituitary-thyroid axis. All the female-to-male transsexuals had regular menstrual cycles (28-31 days) before cross-gender sex-hormone transformation.

All the subjects gave written informed consent and the study was conducted according to the principles of the Declaration of Helsinki and approved by the Ethical Review Committee of the University Hospital Vrije Universiteit (VUMC).

\section{Blood sampling and analysis}

Each subject served as his or her own control. Blood samples for HPT axis hormones and TBG were drawn before and after 4 months of cross-gender sexhormone administration. In female-to-male transsexuals, blood was drawn at baseline between days 5 and 9 of the follicular phase of the menstrual cycle. During testosterone treatment, blood was drawn within 59 days after the most recent testosterone injection.

In-house RIAs were used to measure serum levels of $17 \beta$-estradiol and testosterone. Serum levels of luteinizing hormone (LH) and follicle-stimulating hormone (FSH) were measured by immuno luminometric assays (ILMA).

For thyroid hormones and TSH, the following assays were used: $\mathrm{T}_{4}$ (reference value $70-150 \mathrm{nmol} / \mathrm{l}$, detection limit $5 \mathrm{nmol} / \mathrm{l}$, intraassay coefficient of variance values (CV) $2-4 \%$, interassay CV 3-6\%), $\mathrm{T}_{3}$ (reference value $1.3-2.9 \mathrm{nmol} / \mathrm{l}$, detection limit $0.3 \mathrm{nmol} / \mathrm{l}$, intraassay $\mathrm{CV} 3-4 \%$, interassay $\mathrm{CV} 7-8 \%$ ) and $\mathrm{rT}_{3}$ (reference value $0.11-0.44 \mathrm{nmol} / \mathrm{l}$, detection limit $0.03 \mathrm{nmol} / \mathrm{l}$, intraassay $\mathrm{CV} 4-5 \%$, interassay $\mathrm{CV}$ 5-9\%) were measured by in-house RIA methods (9); free $\mathrm{T}_{4}\left(\mathrm{FT}_{4}\right)$ and TSH were measured by time-resolved fluoroimmunoassay (Delfia $\mathrm{FT}_{4}$ and Delfia hTSH Ultra respectively, Wallac Oy, Turku, Finland: reference value $10-23 \mathrm{pmol} / \mathrm{l}$ and $0.4-4.0 \mathrm{mU} / \mathrm{l}$, detection limit $2 \mathrm{pmol} / \mathrm{l}$ and $0.01 \mathrm{mU} / \mathrm{l}$, intraassay $\mathrm{CV} 4-6$ and $1-2 \%$, interassay CV $5-8$ and $3-4 \%$ respectively); TBG by a commercial RIA (Eiken Chemical Co., Tokyo, Japan; reference value $200-650 \mathrm{nmol} / \mathrm{l}$, detection limit 30 $\mathrm{nmol} / \mathrm{l}$, intraassay CV 2-4\%, interassay CV 4-6\%).

\section{Statistical analysis}

Data are reported as mean \pm s.E.M. ANOVA was used to test for differences between treatment groups. When appropriate a post hoc analysis was performed using Fisher's least significant difference test. Student's $t$-test for paired samples was used to test for differences within treatment groups, i.e. differences between values at baseline and after 4 months of treatment. A $P$-value of less than 0.05 was considered statistically significant. SPSS for windows 11.5 software (SPSS Inc., Chicago, IL, USA) was used to perform the statistical analysis.

\section{Results}

At baseline, all subjects were eugonadal and euthyroid by clinical and laboratory criteria. Baseline characteristics are presented in Tables 1 and 2.

\section{Pituitary-gonadal axis (Table 2)}

Administration of oral EE or transdermal $17 \beta$-estradiol, in combination with CA, suppressed serum LH, FSH, and testosterone concentrations to similar levels. Oral administration of EE decreased serum $17 \beta$-estradiol concentrations, because EE suppresses endogenous $17 \beta$-estradiol and is not detected in conventional $17 \beta$-estradiol assays. Administration of CA alone did not reduce LH or FSH, but decreased serum levels of 
Table 1 Patient characteristics.

\begin{tabular}{|c|c|c|c|c|}
\hline & \multicolumn{3}{|c|}{ Male-to-female transsexuals } & \multirow{2}{*}{$\begin{array}{c}\text { Female-to-male transsexuals } \\
\text { Testosterone } \\
(n=14)\end{array}$} \\
\hline & $\begin{array}{l}\text { Oral ethinyl estradiol } \\
\text { plus } \mathrm{CA}(n=14)\end{array}$ & $\begin{array}{c}\text { Transdermal } 17 \beta \text {-estradiol } \\
\text { plus CA }(n=12)\end{array}$ & $\begin{array}{c}\text { Cyproterone } \\
\text { acetate }(n=10)\end{array}$ & \\
\hline $\begin{array}{l}\text { Age (years) } \\
\text { BMl }\left(\mathrm{kg} / \mathrm{m}^{2}\right) \\
\text { Smoking (n) }\end{array}$ & $\begin{array}{c}32 \pm 2 \\
23 \pm 1 \\
8\end{array}$ & $\begin{array}{c}30 \pm 2 \\
21 \pm 1 \\
6\end{array}$ & $\begin{array}{c}34 \pm 3 \\
22 \pm 1 \\
4\end{array}$ & $\begin{array}{c}28 \pm 2 \\
23 \pm 1 \\
8\end{array}$ \\
\hline
\end{tabular}

Data are means \pm S.E.M. Cyproterone acetate, CA; body mass index, BMI.

$17 \beta$-estradiol and testosterone, although not as extensively as in combination with estrogens. Testosterone administration in female-to-male transsexuals increased plasma testosterone 16 -fold and decreased $17 \beta$-estradiol by suppression of LH and FSH.

\section{Pituitary-thyroid axis and thyroid-binding globulin (Table 3)}

As anticipated, TBG concentrations increased by 100\% after oral, but not after transdermal estrogen administration. TBG concentrations decreased by $14 \%$ after testosterone administration and were not affected by CA. Changes in $\mathrm{T}_{4}$ concentrations in response to treatment paralleled the changes observed with TBG. Plasma-free $\mathrm{T}_{4}$ concentrations were not different between the treatment groups. Comparable to $\mathrm{T}_{4}, \mathrm{~T}_{3}$ increased after oral, but not after transdermal estrogen administration. As a consequence, $\mathrm{T}_{3} / \mathrm{T}_{4}$ ratios were not different between patients treated with oral or transdermal estrogens. In contrast to estrogens, the administration of testosterone differently affected $\mathrm{T}_{4}$ and $\mathrm{T}_{3} . \mathrm{T}_{4}$ decreased, while $\mathrm{T}_{3}$ did not change, which resulted in a higher $\mathrm{T}_{3} / \mathrm{T}_{4}$ ratio after testosterone administration. In contrast to testosterone, CA administration significantly decreased the $\mathrm{T}_{3} / \mathrm{T}_{4}$ ratio, but the magnitude of this decrease was not large enough to result in a difference compared to combined administration of estrogens and CA. TSH concentrations were not different at baseline or after treatment, irrespective of the type of treatment.

\section{Discussion}

Sex-hormone administration in cross-gender transformations provides a unique setting to evaluate the effects of sex hormones on the pituitary-thyroid axis and peripheral thyroxine metabolism in humans. As anticipated, oral estrogen administration increased TBG concentrations, whereas testosterone decreased TBG concentrations. Testosterone administration increased $\mathrm{T}_{3} / \mathrm{T}_{4}$ ratios, indicating increased 5'-deiodinase activity, whereas CA decreased $\mathrm{T}_{3} / \mathrm{T}_{4}$ ratios, suggesting a decreased activity of 5'-deiodinase. Oral or transdermal estrogen administration, combined with $\mathrm{CA}$, had no effect on $\mathrm{T}_{3} / \mathrm{T}_{4}$ ratios.

Plasma $\mathrm{T}_{3} / \mathrm{T}_{4}$ ratios may be used as a marker of extrathyroidal $\mathrm{T}_{4}$ to $\mathrm{T}_{3}$ conversion, but several assumptions have to be met:

(i) Steady state is achieved: sex-steroid administration alters TBG concentrations. As a result, under

Table 2 Gonadal and gonadotropic hormone concentrations at baseline and after 4 months of hormonal treatment in cross-gender transformations.

\begin{tabular}{|c|c|c|c|c|}
\hline & \multicolumn{3}{|c|}{ Male-to-female transsexuals } & \multirow{2}{*}{$\begin{array}{c}\text { Female-to-male transsexuals } \\
\text { Testosterone } \\
(n=14)\end{array}$} \\
\hline & $\begin{array}{l}\text { Oral ethinyl estradiol } \\
\text { plus } C A(n=14)\end{array}$ & $\begin{array}{l}\text { Transdermal } 17 \beta \text {-estra- } \\
\text { diol plus CA }(n=12)\end{array}$ & $\begin{array}{l}\text { Cyproterone acetate } \\
\qquad(n=10)\end{array}$ & \\
\hline \multicolumn{5}{|l|}{ LH (IU/I) } \\
\hline Baseline & $3.2 \pm 0.4^{\mathrm{a}}$ & $2.6 \pm 0.5^{\mathrm{a}}$ & $2.4 \pm 0.4^{\mathrm{a}}$ & $5.7 \pm 1.0^{\mathrm{b}}$ \\
\hline 4 months & $0.3 \pm 0.0^{\mathrm{a}}$ & $0.5 \pm 0.1^{\mathrm{a}}$ & $2.4 \pm 0.4^{b}$ & $2.4 \pm 0.6^{\mathrm{b}}$ \\
\hline \multicolumn{5}{|l|}{$\mathrm{FSH}(\mathrm{IU} / \mathrm{I})$} \\
\hline Baseline & $3.5 \pm 0.5^{\mathrm{a}}$ & $3.9 \pm 1.2^{\mathrm{a}}$ & $3.7 \pm 0.9^{\mathrm{a}}$ & $4.3 \pm 0.3^{a}$ \\
\hline 4 months & $0.5 \pm 0.0^{\mathrm{a}}$ & $0.5 \pm 0.0^{\mathrm{a}}$ & $2.4 \pm 0.6^{b}$ & $2.9 \pm 0.3^{b}$ \\
\hline \multicolumn{5}{|c|}{$17 \beta$-estradiol $(\mathrm{pmol} / \mathrm{l})$} \\
\hline Baseline & $97 \pm 9^{a}$ & $83 \pm 5^{a}$ & $83 \pm 6^{a}$ & $193 \pm 26^{b}$ \\
\hline 4 months & $24 \pm 1^{a} \dagger$ & $175 \pm 37^{b}$ & $41 \pm 4^{a}$ & $126 \pm 11^{\mathrm{b}}$ \\
\hline \multicolumn{5}{|c|}{ Testosterone (nmol/l) } \\
\hline Baseline & $22.3 \pm 1.6^{\mathrm{a}}$ & $22.0 \pm 1.8^{\mathrm{a}}$ & $19.6 \pm 2.0^{\mathrm{a}}$ & $1.9 \pm 0.2^{b}$ \\
\hline 4 months & $1.0 \pm 0.0^{\mathrm{a}}$ & $1.1 \pm 0.1^{\mathrm{a}}$ & $8.8 \pm 1.9^{b}$ & $32.9 \pm 2.6^{\mathrm{C}}$ \\
\hline
\end{tabular}

Data are means \pm S.E.M. Means in a row with different superscript letters are significantly different, $P<0.05$. $\dagger$ Ethinyl estradiol, which suppresses endogenous $17 \beta$-estradiol, is not detected in conventional $17 \beta$-estradiol assays. Cyproterone acetate, CA. 
Table 3 Thyroid hormone and TBG concentrations at baseline and after 4 months of hormonal treatment in cross-gender transformations.

\begin{tabular}{|c|c|c|c|c|}
\hline & \multicolumn{3}{|c|}{ Male-to-female transsexuals } & \multirow{2}{*}{$\begin{array}{c}\text { Female-to-male transsexuals } \\
\begin{array}{c}\text { Testosterone } \\
(n=14)\end{array}\end{array}$} \\
\hline & $\begin{array}{l}\text { Oral ethinyl estradiol } \\
\text { plus CA }(n=14)\end{array}$ & $\begin{array}{c}\text { Transdermal } 17 \beta \text {-estradiol } \\
\text { plus CA }(n=12)\end{array}$ & $\begin{array}{l}\text { Cyproterone acetate } \\
\quad(n=10)\end{array}$ & \\
\hline \multicolumn{5}{|l|}{$\mathrm{T}_{4}(\mathrm{nmol} / \mathrm{l})$} \\
\hline Baseline & $109 \pm 7$ & $118 \pm 7$ & $125 \pm 7$ & $129 \pm 6$ \\
\hline 4 months & $150 \pm 9^{*}$ & $135 \pm 8$ & $122 \pm 6$ & $94 \pm 4^{*}$ \\
\hline$\%$ change & $42 \pm 10^{a}$ & $17 \pm 7^{b}$ & $-2 \pm 4^{b}$ & $-26 \pm 3^{c}$ \\
\hline \multicolumn{5}{|l|}{$\mathrm{T}_{3}(\mathrm{nmol} / \mathrm{l})$} \\
\hline Baseline & $1.71 \pm 011$ & $1.78 \pm 0.14$ & $2.08 \pm 0.13$ & $1.83 \pm 0.11$ \\
\hline 4 months & $2.32 \pm 0.15^{\star}$ & $1.93 \pm 0.19$ & $1.83 \pm 0.11^{*}$ & $1.66 \pm 0.07$ \\
\hline$\%$ change & $44 \pm 14^{\mathrm{a}}$ & $12 \pm 12^{\mathrm{b}}$ & $-11 \pm 2^{b}$ & $-7 \pm 5^{b}$ \\
\hline \multicolumn{5}{|l|}{$\mathrm{T}_{3} / \mathrm{T}_{4}$ ratio } \\
\hline Baseline & $1.60 \pm 0.10$ & $1.57 \pm 0.14$ & $1.67 \pm 0.07$ & $1.44 \pm 0.10$ \\
\hline 4 months & $1.57 \pm 0.08$ & $1.46 \pm 0.13$ & $1.51 \pm 0.06^{\star}$ & $1.80 \pm 0.10^{*}$ \\
\hline$\%$ change & $2 \pm 7^{\mathrm{a}}$ & $-3 \pm 8^{a}$ & $-9 \pm 3^{a}$ & $30 \pm 9^{b}$ \\
\hline \multicolumn{5}{|l|}{$\mathrm{T}_{3} / \mathrm{rT}_{3}$ ratio } \\
\hline Baseline & $8.38 \pm 0.75$ & $7.81 \pm 0.43$ & $6.69 \pm 0.58$ & $5.49 \pm 1.05$ \\
\hline 4 months & $10.10 \pm 0.59$ & $8.63 \pm 0.75$ & $6.61 \pm 0.47$ & $5.22 \pm 1.02$ \\
\hline$\%$ change & $34 \pm 15^{\mathrm{a}}$ & $14 \pm 10^{\mathrm{a}}$ & $5 \pm 11^{a}$ & $32 \pm 39^{\mathrm{a}}$ \\
\hline \multicolumn{5}{|l|}{$\mathrm{fT}_{4}(\mathrm{pmol} / \mathrm{l})$} \\
\hline Baseline & $15.8 \pm 0.5$ & $16.4 \pm 0.7$ & $15.8 \pm 0.6$ & $16.3 \pm 0.4$ \\
\hline 4 months & $14.2 \pm 0.5^{\star}$ & $15.3 \pm 0.8$ & $15.2 \pm 0.4$ & $13.8 \pm 0.4^{\star}$ \\
\hline$\%$ change & $-9 \pm 4^{\mathrm{a}}$ & $-6 \pm 4^{a}$ & $-3 \pm 3^{a}$ & $-15 \pm 2^{a}$ \\
\hline \multicolumn{5}{|l|}{$\mathrm{rT}_{3}(\mathrm{nmol} / \mathrm{l})$} \\
\hline Baseline & $0.22 \pm 0.02$ & $0.23 \pm 0.02$ & $0.34 \pm 0.05$ & $0.40 \pm 0.04$ \\
\hline 4 months & $0.24 \pm 0.02$ & $0.23 \pm 0.02$ & $0.29 \pm 0.02$ & $0.38 \pm 0.03$ \\
\hline$\%$ change & $14 \pm 8^{\mathrm{a}}$ & $0 \pm 5^{\mathrm{a}}$ & $-9 \pm 7^{\mathrm{a}}$ & $13 \pm 22^{\mathrm{a}}$ \\
\hline \multicolumn{5}{|l|}{ TBG (nmol/l) } \\
\hline Baseline & $289 \pm 19$ & $288 \pm 18$ & $336 \pm 19$ & $338 \pm 19$ \\
\hline 4 months & $569 \pm 43^{*}$ & $345 \pm 31$ & $337 \pm 22$ & $285 \pm 15^{*}$ \\
\hline$\%$ change & $100 \pm 12^{a}$ & $23 \pm 14^{b}$ & $0 \pm 2^{\mathrm{bc}}$ & $-14 \pm 4^{c}$ \\
\hline \multicolumn{5}{|l|}{$\mathrm{TSH}(\mathrm{mU} / \mathrm{l})$} \\
\hline Baseline & $1.57 \pm 0.22$ & $1.39 \pm 0.19$ & $1.80 \pm 0.34$ & $1.57 \pm 0.16$ \\
\hline 4 months & $1.59 \pm 0.26$ & $1.59 \pm 0.15$ & $1.28 \pm 0.24$ & $1.36 \pm 0.22$ \\
\hline$\%$ change & $9 \pm 12^{a}$ & $43 \pm 27^{\mathrm{a}}$ & $-16 \pm 17^{a}$ & $-3 \pm 16^{\mathrm{a}}$ \\
\hline
\end{tabular}

Date are means \pm S.E.M. Baseline values between the treatment groups are not different with two exceptions: $\mathrm{rT}_{3}$ is higher in the cyproterone and testosterone groups compared to the estrogen groups and $\mathrm{T}_{3} / \mathrm{r} \mathrm{T}_{3}$ ratio is lower in the testosterone group compared to the estrogen groups, $P<0.05$. Means in a row with different superscript letters are significantly different, $P<0.05$. ${ }^{*}$ Indicates a significant difference compared to the baseline value, $P<0.05$. Cyproterone acetate, CA.

non-steady state conditions, the availability of free $\mathrm{T}_{4}$ and $\mathrm{T}_{3}$ for deiodination could fluctuate, resulting in different $\mathrm{T}_{3} / \mathrm{T}_{4}$ ratios independent of $5^{\prime}$-deiodinase activity. However, it seems safe to assume that steady state was achieved, since we studied the subjects after 8 weeks of sex-steroid administration, which is more than five times the half-life of $\mathrm{T}_{4}$ and TBG (10).

(ii) The ratio of thyroidal $T_{3}$ to $T_{4}$ secretion is constant: different plasma $\mathrm{T}_{3} / \mathrm{T}_{4}$ ratios could just reflect changed $\mathrm{T}_{3} / \mathrm{T}_{4}$ secretion ratios. Various conditions influence thyroidal $\mathrm{T}_{3} / \mathrm{T}_{4}$ secretion ratios. Iodine deficiency results in preferential excretion of $\mathrm{T}_{3}$ and consequently lower $\mathrm{T}_{3} / \mathrm{T}_{4}$ secretion and plasma ratios. During transition from euthyroidism to hypothyroidism, $\mathrm{T}_{4}$ decreases before $\mathrm{T}_{3}$ and vice versa for hyperthyroidism. Neither of these conditions, iodine deficiency nor dysthyroidism, were present in our study subjects.

(iii) Deiodinase type 3 (D3) activity is constant: recently, D3 tissue distribution in humans has been characterized $(11,12)$, but the regulation of $\mathrm{D} 3$ activity in humans is largely unknown. Because of this lack of information on D3 regulation, there is currently no basis to support or reject the third assumption.

(iv) Plasma $T_{3}$ and $T_{4}$ concentrations reflect tissue concentrations: disproportionate $\mathrm{T}_{3} / \mathrm{T}_{4}$ ratios in tissue and plasma would invalidate the plasma $\mathrm{T}_{3} / \mathrm{T}_{4}$ ratio as an indicator of peripheral $\mathrm{T}_{4}$ to $\mathrm{T}_{3}$ conversion, but it was recently shown that plasma $\mathrm{T}_{3}$ and $\mathrm{T}_{4}$ concentrations correlate closely to liver and muscle concentrations (13).

TBG binds approximately $75 \%$ of circulating $\mathrm{T}_{4}$. The remainder is bound to transthyretin or albumin and only a very small fraction $(0.1 \%)$ remains unbound. TBG has the highest affinity for $\mathrm{T}_{4}$ of the $\mathrm{T}_{4}$ binding proteins. The present study shows that oral estradiol administration increases TBG concentrations, whereas transdermal administration did not, confirming the previous observations (1). Two mechanisms are involved in the 
estrogen stimulation of TBG concentrations, namely increased production and reduced clearance of TBG. In primates, high-dose estrogen administration stimulated TBG production and secretion by the liver (14). Estrogens also stimulated the formation of more heavily sialylated TBGs (15), which exhibit a slower clearance rate from plasma than less sialylated TBG (16). It appears that estrogen stimulation of TBG only occurs above a certain portal threshold, which explains why only oral administration of low-dose estrogens, with a relatively high portal concentration, and high systemic concentrations, as observed in pregnancy (17), increase TBG concentrations. As anticipated $(3,18)$, testosterone decreased TBG concentrations. Whether testosterone decreases TBG by reduced synthesis or enhanced clearance is not known. CA did not affect TBG concentrations. CA has three modes of action; it has progestinic, anti-androgenic and anti-gonadotropic effects. Previous studies do not support an effect of progestins on TBG (19). Although the anti-androgenic effects of CA could theoretically increase TBG concentrations, we did not observe such an effect.

In humans plasma $\mathrm{T}_{3}$ comes from two, relatively independent sources, namely thyroid secretion and extrathyroidal conversion of $\mathrm{T}_{4}$ by $5^{\prime}$-deiodinase with a relative contribution of 20 and $80 \%$ respectively (20). Three types of deiodinase exist, but only D1 and D2 have 5'-deiodinase capability. In euthyroid humans, the relative contributions of D1 and D2 to extrathyroidal $\mathrm{T}_{3}$ production are approximately 34 and $66 \%$ (4). The effects of sex steroids on $5^{\prime}$-deiodinase activity have thus far only been studied in rats, but thyroid hormone metabolism in rats is markedly different from humans. In rats, thyroid secretion accounts for $40 \%$ of plasma $\mathrm{T}_{3}$ and extrathyroidal $5^{\prime}$-deiodination of $\mathrm{T}_{4}$ by $\mathrm{D} 1$ and $\mathrm{D} 2$, each for $30 \%$. In rats, D2 is not expressed in muscle and contributes significantly less to plasma $\mathrm{T}_{3}$ as compared to humans. Only a limited number of studies (summarized in the Introduction) have studied the effects of sex hormones in rats on D1 activity in the liver. Low-dose estrogens did not affect hepatic D1 activity, whereas testosterone increased D1 activity. Currently, there is no evidence to support an effect of androgens or estrogens on D2 activity, but the data are limited to D2 activity in the rat pituitary (6) and the mouse bone (21). Whether testosterone increased $\mathrm{T}_{4}$ to $\mathrm{T}_{3}$ conversion by effects on $\mathrm{D} 1$ or $\mathrm{D} 2$ remains speculative. $\mathrm{CA}$ decreased $\mathrm{T}_{3} / \mathrm{T}_{4}$ ratios suggesting decreased $\mathrm{T}_{4} 5^{\prime}$-deiodination. The effect of $\mathrm{CA}$ on $\mathrm{T}_{3} / \mathrm{T}_{4}$ ratios could be induced by the anti-androgenic effect, but also by the progestinic effect of CA. In rats progestin decreased hepatic and pituitary D1 activity (6). Unfortunately, we could only study the effects of estrogens with concurrent $\mathrm{CA}$ administration. Therefore, we cannot exclude that a potential effect of estrogens was blunted by CA.

In conclusion, oral but not transdermal estrogens increased TBG and testosterone decreased TBG. Estradiol combined with $\mathrm{CA}$ did not affect $\mathrm{T}_{3} / \mathrm{T}_{4}$ ratios, whereas testosterone increased $\mathrm{T}_{3} / \mathrm{T}_{4}$ ratios.

\section{References}

1 Arafah BM. Increased need for thyroxine in women with hypothyroidism during estrogen therapy. New England Journal of Medicine 2001344 1743-1749.

2 Chetkowski RJ, Meldrum DR, Steingold KA, Randle D, Lu JK, Eggena P, Hershman JM, Alkjaersig NK, Fletcher AP \& Judd HL. Biologic effects of transdermal estradiol. New England Journal of Medicine 1986314 1615-1620.

3 Arafah BM. Decreased levothyroxine requirement in women with hypothyroidism during androgen therapy for breast cancer. Annals of Internal Medicine 1994121 247-251.

4 Luiza Maia A, Kim BW, Huang SA, Harney JW \& Larsen PR. Type 2 iodothyronine deiodinase is the major source of plasma T3 in euthyroid humans. Journal of Clinical Investigation 2005115 2524-2533.

5 Miyashita K, Murakami M, Iriuchijima T, Takeuchi T \& Mori M. Regulation of rat liver type 1 iodothyronine deiodinase mRNA levels by testosterone. Molecular and Cellular Endocrinology 1995 $115161-167$.

6 Lisboa PC, Curty FH, Moreira RM, Oliveira KJ \& Pazos-Moura CC. Sex steroids modulate rat anterior pituitary and liver iodothyronine deiodinase activities. Hormone and Metabolic Research 2001 $33532-535$.

7 Harris AR, Vagenakis AG \& Braverman LE. Sex-related differences in outer ring monodeiodination of thyroxine and $3,3^{\prime}, 5^{\prime}$ triiodothyronine by rat liver homogenates. Endocrinology 1979 $104645-652$.

8 Giltay EJ, Gooren LJ, Emeis JJ, Kooistra T \& Stehouwer CD. Oral, but not transdermal, administration of estrogens lowers tissue-type plasminogen activator levels in humans without affecting endothelial synthesis. Arteriosclerosis, Thrombosis, and Vascular Biology 200020 1396-1403.

9 Wiersinga WM \& Chopra IJ. Radioimmunoassay of thyroxine (T4), 3,5,3'-triiodothyronine (T3), 3,3',5'-triiodothyronine (reverse T3, rT3), and 3,3'- diiodothyronine (T2). Methods in Enzymology 1982 84 272-303.

10 Refetoff S, Fang VS, Marshall JS \& Robin NI. Metabolism of thyroxine-binding globulin in man. Abnormal rate of synthesis in inherited thyroxine-binding globulin deficiency and excess. Journal of Clinical Investigation $1976 \mathbf{5 7} 485-495$.

11 Alkemade A, Friesema EC, Unmehopa UA, Fabriek BO, Kuiper GG, Leonard JL, Wiersinga WM, Swaab DF, Visser TJ \& Fliers E. Neuroanatomical pathways for thyroid hormone feedback in the human hypothalamus. Journal of Clinical Endocrinology and Metabolism $2005904322-4334$.

12 Hernandez A, Martinez ME, Croteau W \& StGermain DL. Complex organization and structure of sense and antisense transcripts expressed from the DIO3 gene imprinted locus. Genomics $2004 \mathbf{8 3}$ 413-424.

13 Peeters RP, van der Geyten S, Wouters PJ, Darras VM, van Toor H, Kaptein E, Visser TJ \& Van den Berghe G. Tissue thyroid hormone levels in critical illness. Journal of Clinical Endocrinology and Metabolism $2005906498-6507$.

14 Glinoer D, Gershengorn MC, Dubois A \& Robbins J. Stimulation of thyroxine-binding globulin synthesis by isolated rhesus monkey hepatocytes after in vivo beta-estradiol administration. Endocrinology 1977100 807-813.

15 Gartner R, Henze R, Horn K, Pickardt CR \& Scriba PC. Thyroxinebinding globulin: investigation of microheterogeneity. Journal of Clinical Endocrinology and Metabolism 198152 657-664.

16 Ain KB, Mori Y \& Refetoff S. Reduced clearance rate of thyroxinebinding globulin (TBG) with increased sialylation: a mechanism for estrogen-induced elevation of serum TBG concentration. Journal of Clinical Endocrinology and Metabolism 198765 689-696.

17 Glinoer D, de Nayer P, Bourdoux P, Lemone M, Robyn C, van Steirteghem A, Kinthaert J \& Lejeune B. Regulation of maternal thyroid during pregnancy. Journal of Clinical Endocrinology and Metabolism 199071 276-287. 
18 Deyssig R \& Weissel M. Ingestion of androgenic-anabolic steroids induces mild thyroidal impairment in male body builders. Journal of Clinical Endocrinology and Metabolism 199376 1069-1071.

19 Cullberg G. Pharmacodynamic studies on desogestrel administered alone and in combination with ethinylestradiol. Acta Obsteticia et Gynecolgica Scandinavica Suppliment 1985133 1-30.

20 Bianco AC, Salvatore D, Gereben B, Berry MJ \& Larsen PR. Biochemistry, cellular and molecular biology, and physiological roles of the iodothyronine selenodeiodinases. Endocrine Reviews 200223 38-89.
21 Gouveia CHA, Christoffolete MA, Zaitune CR, Dora JM, Harney JW, Maia AL \& Bianco AC. Type 2 iodothyronine selenodeiodinase is expressed throughout the mouse skeleton and in the MC3T3-E1 mouse osteoblastic cell line during differentiation. Endocrinology 2005146 195-200.

Received 23 February 2006

Accepted 28 April 2006 